\title{
The impact of service quality on Customer satisfaction of Jordan Insurance Companies
}

\author{
Dr Kamal Ahmad Al qudah ${ }^{1}$, Dr Sulieman H. Al-beshtawi ${ }^{2}$, Dr. Khaled Atallah Al-Tarawneh ${ }^{3}$, \\ Dr. Anber Abraheem Shlash Mohammad ${ }^{4}$, Amr Adel Abu-Laimon ${ }^{5}$ \\ ${ }^{1}$ Associate Professor, Dean, Faculty of Business and Finance, American University of Madaba
}

\section{k.qudah@aum.edu.jo}

${ }^{2}$ Associate professor of accounting, faculty of Business Science, Al-Israa university, Jordan

\section{dr slieman@yahoo.com}

\begin{abstract}
${ }^{3}$ Associate Professor, Marketing Department, Administrative and Financial Sciences Faculty Petra University, Jordan

\section{kaltarawneh@uop.edu.jo,}

${ }^{4}$ Associate Professor, Marketing Department, Administrative and Financial Sciences Faculty Petra University, Jordan
\end{abstract}

\section{Mohammad197119@yahoo.com}

${ }^{5}$ Researcher, The Ministry of Awqaf and Islamic affairs, P.O.BOX 130040, Mafraq 25113, Jordan

\section{efyarmok@yahoo.com}

\section{ABSTRACT}

The study aimed to investigate the impact of service quality on Customer satisfaction of Jordan Insurance Companies. The sample for this study consists customers of Jordan insurance companies. These were randomly selected from customers of ALICO insurance company located in in several locations in Jordan. Two hundred and thirty three usable surveys were returned with a response rate of $58.25 \%$. The (SERVQUAL) identifies seven dimensions of service quality: Competence, Credibility, reliability, responsiveness, Assurance, tangibles, Communication.. The study indicates that there was a statistically significant link between seven dimensions service quality and customer satisfaction. The findings of the study have important implications for managers of Jordan Insurance Companies, managers of Jordan Insurance Companies could make Commitment by the offers provided to the customers, so that the advertised offers should match the reality. Great attention to complaints made by customers and considering them seriously by forming specialized committees to respond to these complaints, and Working on the development of signboards in all centers of the company which include the steps to be followed by customers to receive the service in order to let the customer receives the service quickly and without errors or delay.

Keywords: service quality, Customer satisfaction, Insurance Companies, Jordan.

\section{Council for Innovative Research}

\author{
Peer Review Research Publishing System
}

Journal: International Journal of Management \& Information Technology

Vol. 5, No. 2

editor@cirworld.com

www.cirworld.com, member.cirworld.com 


\section{INTRODUCTION}

Business organizations live circumstances that are characterized by a highly competitive nature among them. The ability of organizations to survive in the market lies in their ability to respond to change and interact with its givens. As the needs and desires of customers were formulated and formed in the light of their economic, cultural and social reality, the relationship becomes strong between the organization's ability to continue and survive, and its ability to produce services fit in with the changing and developing needs of customers. Hence, the management of the company must operate under the belief that: (the ability to develop leads to survive), because the provided service aims to meet the clients' needs and desires. So, one of the surviving factors is that the provided services should meet the clients' needs. The quality of services provided by the organization became a necessary at which its importance increases by increasing the needs, desires and expectations of clients. In this context, quality is no longer just matching services to standard technical specifications set out in advance, but exceeded that, it now includes the desires and requirements of clients' services (AlEnezi, 2002). Quality of service plays an important role in designing the product of the service and its marketing, as it is important for both service providers and clients. The awareness of the service organizations about the importance, role and application of the concept of total quality in achieving competitive advantage has increased. Moreover, the quality topics and issues have captured the attention of a lot of businessmen, seminars and scientific conferences; clients also became more aware and concerned about quality, and thus institutions have emerged concern about monitoring the quality of services in all respects (Abdulkader, 2002).

The quality became of basic necessities to provide the service because it represents the desires of the beneficiaries of those services, and there is a difficulty in measuring the quality of services if we do not explore the views of the beneficiaries about what they expect from the service and about what they got, because the quality of the service is intangible and cannot be measured easily; and thus there is a difficulty in satisfying the customers about the provided service, whose desires and needs differ from one person to another and from time to time. The process of evaluating the service that the clients receive provides new information for the communication management about the appropriateness of various public services offered to customers, and thus this information can be used as a basis for making appropriate decisions on the provision of services, make companies able to continue and develop, as well as compete in the light of economic and administrative changes that overrun the world at present, which require the organizations to make efforts to withstand before competitive organizations.

The customer's satisfaction is one of the service quality elements; and as the service institutions operate under strong competition, they should concern about the desires and requirements of customers in order to gain their loyalty, as well as have new customers by providing quality services better than the services offered by other competitive institutions. The quality of service affects the intention of existing customers to buy back the service, and it effects on potential customers because the unhappy customer about the service will tell other customers about his bad conception towards the organization he dealt with; so the bad service or low quality will lead to reduce the current and potential customers, as well as the process of attracting a new customer will cost the institution many times as much of keeping a current customer.

\section{Theoretical Review and Research development}

\subsection{ALICO insurance company}

ALICO is one of the largest and famous insurance companies in Jordan and the region. It is always offer many insurance plans to satisfy the different needs of its customers. it is not only that but ALICO is a global company which has a lot of branches in Jordan and that will make it easier to customers to get the required support promptly. ALICO provides many types of services such as life insurance, accident insurance, travel insurance and health insurance and there are different planes available of these insurance types.

Alico, has been helping people and businesses in Jordan and PNA with their insurance needs since 1958. Throughout their history, they have continuously sought to nurture talent, respect local cultures and promote the diversity that characterizes the Jordanian and Palestinian societies. They've grown by understanding the needs at the heart of the community and by tailoring, through Agents, Brokers, Banks and Direct channels, their extensive product offering to the unique needs of individuals, families and businesses of all sizes.

\subsection{Service Quality}

Concerning about quality has increased in the eighties, whether for commodities or services in the twentieth century, and the quality became the biggest advantage of provided service and a powerful competitive weapon for parent companies. In spite of the ambiguity in the concept of quality, marketers were able to describe and measure the quality of tangible commodities, but the quality of services has not been agreed upon to be measured yet, and perhaps gaining the client's satisfaction and loyalty can be one of the service quality standards.

The service primarily aims to satisfy the needs and desires of the beneficiaries, and therefore there would be a strong correlation between the beneficiaries of the service and service provider organizations; the service is not just performing an activity, but it should meet the desires and needs of the beneficiaries of the service. It is necessary that managers in the various administrative levels, and the staff who provide the service know how to measure the quality of service, know the specification of high quality service which meets the needs of clients and work to meet these needs, in order to get clients' satisfaction to achieve the goal sought by companies to increase their profitability. 
Berry is considered one of the prominent writers who wrote in the field of services, at which he used the word "Journey" to ensure that the quality of the service is not just an editing program, but it is an infinite journey (Melani, 1999). In addition, services and marketing literature have shown many definitions which addressed defining the concept of service, as defined by the American Society of marketing that the service: "is the activities or benefits offered for sale or offered for its association with a particular commodity" (Al-dhmour, 2002). However, this definition did not distinguish adequately between the commodity and service. Kotler and Armstrong, (2001) have defined the service as "an activity or benefit that can be provided by another party which is mainly intangible, resulting not to own anything, and service delivery methods may or may not be linked to a material product". Station, (1967) has pointed out that the service is "an intangible activity aims to satisfy the desires and needs when they are marketed to the final consumer or industrial buyer for the payment of a certain amount, and services should not be combined with the selling of other products". While Hakesever et al., (2000) have defined the service as "a set of economic activities that provide time, place, shape and psychological benefits". Zeithaml and Bitner believe that the service is "acts, processes, achievements and work" (Al-dhmour, 2002).

There are many definitions of the concept of service quality because it is very difficult to determine a single definition of quality; in our first concept, quality has been defined by (Berry) as (compliance with requirements) (Daaboul, 2003), which means that companies must put the requirements and specifications; and once these specifications are placed, the goal of quality for various corporate functions is to adhere to these specifications strictly. The organizations which are characterized by their high quality services will certainly get a high market share and the returns on investment are larger than other similar organizations, which services are of low quality; this leads us to say that the quality is one of the most important factors affecting the performance of organizations and their survival in the market under the high competition and the long-term. Despite the growing importance of the services sector and the importance of quality as a competitive factor, the concept of quality of services is still tainted by some mystery unlike the concept of material commodities' quality which is measured and determined accurately. The concept of commodities' quality is the existence of "a set of product properties that determine its suitability in order to perform the required function as expected by the consumer, where these properties vary from one product to another" (Al-Shati, 1993).

(Brain and Marson) have defined the quality of service as "knowing what the client wants and achieving that desire correctly without imperfections and defects from the first time. So that the consumer does not have to back to the employee again to amend an error or failure, in addition to achieving the continuity in the quality of service and improving the performance (Robert \& Denhardt, 1991). Parasuraman, et al., (1988) have also defined it as ""conformity with the specifications of the consumer, as the quality is how defined by the consumer not the management". Moreover, Robinson, (1999) has defined it as "a comprehensive directional rule towards service excellence, although the exact nature of this direction is not agreed upon."

\subsection{Measuring the Quality of Service}

The achievement of the quality of services is a goal and a marketing tool at the same time, because achieving high quality services leads to achieving the clients' satisfaction, so companies must measure the quality of services. In 1988, Parasuraman and others examined the sample of the service quality which was improved in 1985. .These researchers developed a sample called SERVQUAL for measuring the quality of service. This sample is based on perceived quality; this study has identified that there is a possibility to ignore the original ten dimensions of quality of service, or there is a possibility for the lack of a high associational relationship between these dimensions, so that it is retrieved within the form. SERVQUAL evaluates these five distinctive dimensions; these researchers have also felt that these five dimensions are able to access the aspects of the original ten dimensions, and these dimensions are (Roa, 1996):

1 - Tangible things: material facilities, equipment, tools and the appearance of the workers and employees.

2 - Reliability: the ability to perform the promised service accurately and reliably.

3 - Responsiveness: the desire to help customers and provide good service.

4 -Safety: knowledge and politeness of staff, their ability to inspire and create confidence for the consumer.

5 - Empathy: personal care about the consumer and personal attention provided by the company to its customers.

Based on the model of Gronroos (1984), material aspects could be classified (Tangible), safety, compassion, as functional dimensions of service quality. Stability and responsiveness can be classified as technical dimensions; however, and as defined by Parasuraman, et al, (1988), respond can be considered as a functional dimension of quality. Researchers have also included seven original dimensions in building warranty and sympathy, and these dimensions are: communication, safety, confidence, ability, knowledge, understanding the consumer, courtesy and accessibility.

\subsection{Customers Satisfaction}

At a time the markets are overwhelmed by similar suppliers, similar goods and services, the competition intensified, and the modern technologies have entered on the line to change the picture radically and changed the rules of the game, so financial pressures and administrative problems have increased, as it became difficult to differentiate by competitors, and ambiguity has surrounded the process of achieving customers' satisfaction. We find companies of different competencies and areas striving to chime in with the needs of its customers, and their offers meet their requirements to achieve their satisfaction, and it is declared explicitly and clearly in their annual reports and various bulletins that: We are committed to achieve the highest levels of customers' satisfaction, but such permits remain dead letters, and efforts are lost in vain, unless they are accompanied by appropriate effective actions in this desired direction; the only way to achieve that is to 
know what customers really want, therefore the importance of correct scientific measurement of customer satisfaction increases in these difficult circumstances. There are a lot of surveys to measure customer satisfaction that give wrong results because of its poor design, or poor selection of data collection method, or bad analysis; therefore, surveys should be designed on a high level of precision for measuring customer satisfaction, to get the results they can rely on in selecting decisions and appropriate actions to achieve customer satisfaction and keep it.

The customer satisfaction has become important to the extent that some service institutions consider it as a key element in their marketing strategies, as the term "post-marketing" is used widely to mean to focus attention and efforts on current customers in order to maximize the level of satisfaction they have and ensure keeping them (Havra, 1995). Many studies have addressed the definition of customers' satisfaction. Customers' satisfaction has been defined as: the feeling or attitude customers about the product or service after use, so that the satisfied customer about a service or product will use it once again, in addition to the transfer of such good feeling to others and encourage them to experience this item or service. In sharp contrast, the unhappy customer with the service or product will look for another product or service that meets his needs and desires and bring him satisfaction, in addition to the transfer of this negative feeling about the product or service to others and warn them not to use it, this in turn is reflected on the institution or organization image in the minds of others, Metawa \& Almossawai, (1998). (Batson) has defined satisfaction as: the final output of the assessment conducted by the beneficiary for a certain reciprocal process (Al-Allaq and Al-Taei, 2007). Moreover, customer satisfaction can be defined as a satisfactory psychological condition or complacency by the customer as a result of the success of the organization in achieving the desires and needs of the client for once, which happens when the provided services of organization match the expectations and perceptions of the client; in this case, satisfaction is a situational and attitudinal psychological condition changes and fluctuates in the intensity and nature according to the change in the nature and direction of the relationship between the organization and the client. While loyalty is a psychological satisfactory condition results from the continued and repeated success of the organization in achieving the satisfaction of its client; it is a psychological condition makes the client feels his loyalty and allegiance to the organization which reflects the reaction as a result of the relationship and the repeated satisfactory performance by the organization, as well as the severity of its strength is shown through the client's behavior towards the organization and its products; this feeling is existed based on absolute confidence and a high extent of reliability. Ramaswamy, (1996) has also defined customers satisfaction in the light of his research in the quality of service that: it is matching expectations with perceived quality; if the perceived quality has coincided with the expectations of customers, the customer will be satisfied about this service, and if they do not match, the customer will feel dissatisfied with the service.

\subsection{The Relationship between the Perceived Service Quality and the Beneficiary Satisfaction}

There is ambiguity and confusion about the relationship between the perceived service quality and customer satisfaction, and that because the lack of common ground between the two concepts, in addition to the lack of a clear and accurate vision about the nature, identity and how the interrelationship between the two concepts. However, some researchers believe that the satisfaction falls within the concept of quality, and quality leads to customer satisfaction; and some think that satisfaction and quality reflect the same concept, while others think that the satisfaction and quality are separated concepts from each other and satisfaction is a factor and mediator between perception of quality and intentions of purchasing (Al-Enezi, 2002). Bateson, (2004) has distinguished between the quality of service and customers satisfaction; Quality is the attitude made by the client through the assessment of the service offering. This position is formed through previous experience of the client; while the satisfaction is the final output of the assessment conducted by the beneficiary for the process of a certain exchange. Anderson etal., (1994) in an attempt to distinguish between customer satisfaction and service quality through the concept of beneficiary satisfaction based on cumulative exchanges, it is about past experiences gained by the client through the purchase and consumption of a commodity or service within a certain period of time. Accordingly, the performance of service supplier can be evaluated in the past, present and future.. As a result of the above literature review, the research hypothesis is:

\section{H1. Service quality directly influences Customer satisfaction of Jordan insurance companies .}

More specifically:

H1a. Competence directly influences Customer satisfaction of Jordan insurance companies .

H1b. Credibility directly influences Customer satisfaction of Jordan insurance companies .

H1c. Reliability directly influences Customer satisfaction of Jordan insurance companies .

H1d. Responsiveness directly influences Customer satisfaction of Jordan insurance companies

H1e. Assurance directly influences Customer satisfaction of Jordan insurance companies .

H1f. Tangibles directly influences Customer satisfaction of Jordan insurance companies .

H1g. Communication directly influences Customer satisfaction of Jordan insurance companies .

\section{RESEARCH FRAMEWORK}

Based on literature review and research hypotheses as illustrated in the last section, this study develop the conceptual framework of this research as shown in Figure 1. 


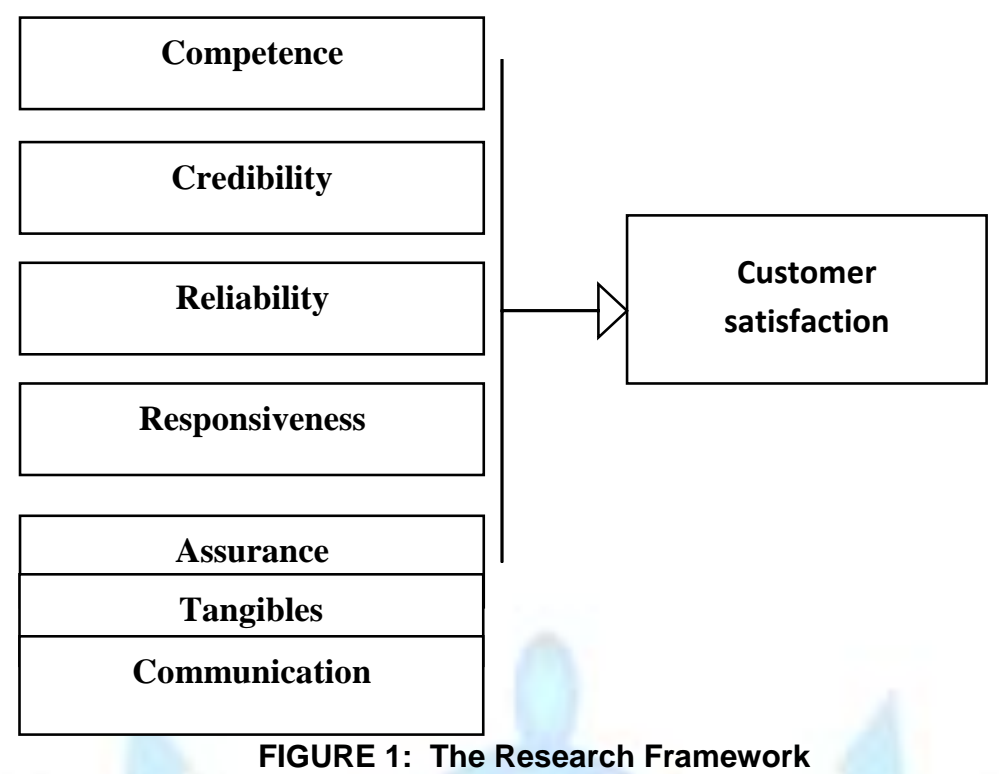

The proposed research framework present the relationship between seven constructs of service quality and customer satisfaction.

\section{METHODOLOGY}

In this section we discuss sample, and operational measures of variables used in the study as well as the statistical tests used to examine the impact of the multidimensionality of perceived service quality on customer satisfaction of Jordan insurance companies.

\subsection{Sample}

The sample for this study consists customers of Jordan insurance companies. These were randomly selected from customers of ALICO insurance company located in in several locations in Jordan. This study was deliberately completed in the months (March to July) in 2013. Participants were told that the study was designed to collect information on the service quality provided by ALICO insurance company in Jordan. They were given confidentially assurances and told that participation was voluntary. The questionnaires were collected immediately. A total of 400 subjects participated in this study. Incomplete questionnaires reduced the sample size to 233 subjects. Two hundred and thirty three usable surveys were returned with a response rate of $58.25 \%$. There were 145 (62.24per cent) male and 88 (37.76 per cent) female. (22.31 per cent) were below 25 years old, (47.64 percent) were between 25 and 35 years old, another (16.74 percent) were between 35 and 45 years old, and (13.30 per cent) were 45 years old and more. Finally, regarding, education, (10.03percent) did hold a High school degree and below, (19.31 percent) did hold a diploma degree, (49.79 per cent) were bachelor degree, and (20.60 percent) were higher education degree, the summary of the sample characteristics shown in table (1).

Table (1) sample characteristics

\begin{tabular}{|c|c|c|c|}
\hline Variable & 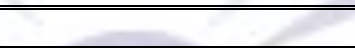 & $\overline{\mathbf{N}}$ & $\%$ \\
\hline \multirow[t]{2}{*}{ Gender } & Male & 145 & $\begin{array}{c}62.2 \\
4\end{array}$ \\
\hline & Female & 88 & 3776 \\
\hline \multirow{4}{*}{ Age } & Less than 25 & 52 & $\begin{array}{c}22.3 \\
1\end{array}$ \\
\hline & 25- less than 35 & 111 & $\begin{array}{c}48.6 \\
4\end{array}$ \\
\hline & 35- less than 45 & 39 & $\begin{array}{c}16.7 \\
4\end{array}$ \\
\hline & 45 and more & 31 & $\begin{array}{c}13.3 \\
0\end{array}$ \\
\hline \multirow{4}{*}{ Education } & High school and below & 24 & $\begin{array}{c}10.0 \\
3\end{array}$ \\
\hline & Diploma & 45 & $\begin{array}{c}19.3 \\
1\end{array}$ \\
\hline & Bach & 116 & $\begin{array}{c}49.7 \\
9\end{array}$ \\
\hline & Higher education & 48 & $\begin{array}{c}20.6 \\
0\end{array}$ \\
\hline
\end{tabular}




\subsection{Measures}

The survey instrument is composed of questions relating to the following two constructs that include service quality, and customer satisfaction.

4.2.1 Independent variable: service quality. This variable was measured by using Parasuraman et al. (1985) (SERVQUAL) due to its wide acceptance (Lam et al., 1997; Gounaris et al., 2003) in the extant literature. They developed a multi-item scale to operationalize the service quality construct in a service context (Parasuraman et al. 1985). A fivepoint Likert scale ranging from "strongly disagree" to "strongly agree" was used. The (SERVQUAL) identifies seven dimensions of service quality: Competence, Credibility, reliability, responsiveness, Assurance, tangibles, Communication.

4.2.1 dependent variable : Customer satisfaction: is the customer's feeling of satisfying his desires when receiving the commodity or service.

\section{RELIABILITY OF RESEARCH INSTRUMENT AND MEASUREMENT SCALES}

After the survey had been completed the reliability of the scales was used to examine the internal consistency of degree of service quality scale between various factors influencing customer satisfaction for validity by computing their coefficient alpha (Cronbach alpha). After analyzing the total scale and respective, a higher a value indicated a higher internal consistency within the questionnaire as a whole (Wang, 2005). According to Sekaran (2000) mention, it is a low and acceptable standard if the Cronbach Alpha is 0.6. All scales were found to exceed a minimum threshold of 0.6 . Convergent validity is also suggested when the individual variable scores are combined into a single scale to give a Cronbach alpha of 0.7923 .

Factors of service quality include Competence, Credibility, reliability, responsiveness, Assurance, tangibles, Communication. Cronbach's a were $.70, .72, .77, .87, .75, .74, .70$ respectively. Customer satisfaction. Cronbach alpha was .78. It has shown that the reliability between service quality, and customer satisfaction was good and it was in accordance with the internal factors. The actual results of the scale reliability analysis are reported in Tables (2) and (3).

Table (2) Scale Reliability of the service quality variables

\begin{tabular}{|c|c|c|c|c|c|}
\hline Construct and item & Mean & SD & $\begin{array}{l}\text { Item to total } \\
\text { correlation }\end{array}$ & $\begin{array}{l}\text { Scale alpha if } \\
\text { item deleted }\end{array}$ & Reliability \\
\hline Competence & & & & & 0.70 \\
\hline $\begin{array}{l}\text { The company's staff has high-efficiency } \\
\text { in providing the service }\end{array}$ & 3.53 & 1.53 & 0.39 & 0.41 & \\
\hline $\begin{array}{l}\text { The company's staff providing services } \\
\text { with highly skills }\end{array}$ & 3.10 & 1.68 & 0.49 & 0.28 & \\
\hline $\begin{array}{l}\text { The company's staff is trying to carry out } \\
\text { their role as best }\end{array}$ & 2.79 & 1.60 & 0.56 & 0.36 & \\
\hline $\begin{array}{l}\text { The company's staff has full knowledge } \\
\text { enable them to carry out their roles }\end{array}$ & 2.67 & 1.52 & 0.48 & 0.42 & \\
\hline $\begin{array}{l}\text { Employees of the company have sufficient } \\
\text { information about the service provided }\end{array}$ & 2.66 & 1.62 & 036 & 0.36 & \\
\hline Credibility & 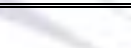 & & & & 0.72 \\
\hline $\begin{array}{l}\text { You feel the credibility of the company in } \\
\text { the implementation of its services }\end{array}$ & 3.11 & 1.52 & 0.28 & 0.46 & \\
\hline $\begin{array}{l}\text { The company employees into confidence } \\
\text { for customers }\end{array}$ & 3.10 & 1.37 & 0.32 & 0.27 & \\
\hline $\begin{array}{l}\text { The company is committed to its promises } \\
\text { toward the customer }\end{array}$ & 3.03 & 1.45 & 0.53 & 0.43 & \\
\hline Offers by the company conform to reality & 2.88 & 1.55 & 0.53 & 0.30 & \\
\hline $\begin{array}{l}\text { The customer pays real value for the } \\
\text { services provided }\end{array}$ & 2.81 & 1.53 & 0.56 & 0.30 & \\
\hline $\begin{array}{l}\text { The company takes into account laws and } \\
\text { regulations in the prices determination }\end{array}$ & 2.80 & 1.43 & 0.49 & 0.35 & \\
\hline Reliability & & & & & 0.77 \\
\hline $\begin{array}{l}\text { The company provides services in time } \\
\text { without delay }\end{array}$ & 3.40 & 1.42 & 0.28 & 0.47 & \\
\hline
\end{tabular}


ISSN 2278-5612

\begin{tabular}{|c|c|c|c|c|c|}
\hline Construct and item & Mean & SD & $\begin{array}{l}\text { Item to total } \\
\text { correlation }\end{array}$ & $\begin{array}{l}\text { Scale alpha if } \\
\text { item deleted }\end{array}$ & Reliability \\
\hline $\begin{array}{l}\text { The company has the capacity to provide } \\
\text { the service without interruption }\end{array}$ & 3.39 & 1.55 & 0.59 & 0.39 & \\
\hline $\begin{array}{l}\text { The company is keen on solving } \\
\text { customers problems regarding services } \\
\text { provided easily }\end{array}$ & 3.31 & 1.54 & 0.60 & 0.38 & \\
\hline $\begin{array}{l}\text { The company's staff has the capacity to } \\
\text { provide services easily }\end{array}$ & 3.18 & 1.55 & 0.68 & 0.47 & \\
\hline $\begin{array}{l}\text { The company's staff providing outstanding } \\
\text { services }\end{array}$ & 3.08 & 1.55 & 0.49 & 0.30 & \\
\hline $\begin{array}{l}\text { The company's staff completing services } \\
\text { correctly for the first time }\end{array}$ & 2.95 & 1.48 & 0.45 & 0.35 & \\
\hline $\begin{array}{l}\text { The company's staff offers you tips in } \\
\text { choosing appropriate service depends on } \\
\text { the nature of your business }\end{array}$ & 2.92 & 1.34 & 0.35 & 0.44 & \\
\hline Responsiveness & & & & & .87 \\
\hline $\begin{array}{l}\text { The company's staff is ready to provide } \\
\text { assistance to you }\end{array}$ & 4.20 & 1.30 & 0.50 & 0.50 & \\
\hline $\begin{array}{l}\text { The company's staff seeks to help you in } \\
\text { solving the problems that you face in } \\
\text { getting service }\end{array}$ & 4.06 & 1.49 & 0.64 & 0.55 & \\
\hline $\begin{array}{l}\text { The company's staff respond to the } \\
\text { customer's needs, whatever the degree of } \\
\text { concern }\end{array}$ & 4.03 & 1.48 & 0.62 & 0.51 & \\
\hline $\begin{array}{l}\text { The company management Concerned } \\
\text { with customer complaints and queries }\end{array}$ & 3.86 & 1.42 & 0.72 & 0.59 & \\
\hline $\begin{array}{l}\text { Some actions may be shortened by } \\
\text { workers with a view to speed customer } \\
\text { service }\end{array}$ & 3.81 & 1.52 & 0.72 & 0.54 & \\
\hline $\begin{array}{l}\text { The company's staff provide service to } \\
\text { customers as a priority entry into the } \\
\text { company without exceeding }\end{array}$ & 3.57 & 1.53 & 0.64 & 0.45 & \\
\hline $\begin{array}{l}\text { The company has a sufficient number of } \\
\text { staff who provide service to customers }\end{array}$ & 3.53 & 1.51 & 0.65 & 0.46 & \\
\hline Assurance & $\bar{c}$ & & & & 75 \\
\hline $\begin{array}{l}\text { You feel reassured in dealing with the } \\
\text { company }\end{array}$ & 3.91 & 1.44 & 0.44 & 0.49 & 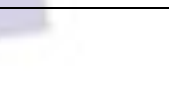 \\
\hline The company provides risk-free services & 3.74 & 1.54 & 0.56 & 0.48 & \\
\hline $\begin{array}{l}\text { The company's staff has high capacities } \\
\text { to provide the service }\end{array}$ & 3.65 & 1.51 & 0.58 & 0.40 & \\
\hline $\begin{array}{l}\text { The company's staff Follows the special } \\
\text { procedures since customer requests } \\
\text { service until submitted }\end{array}$ & 3.48 & 1.55 & 0.48 & 0.40 & \\
\hline $\begin{array}{l}\text { Customers' information Treated fully } \\
\text { confidentiality by the company }\end{array}$ & 3.47 & 1.54 & 0.45 & 0.42 & \\
\hline $\begin{array}{l}\text { The company is keen on the customer } \\
\text { communications to be confidential }\end{array}$ & 3.39 & 1.43 & 0.41 & 0.39 & \\
\hline Tangible & & & & & 0.74 \\
\hline Decent appearance of company's staff & 3.27 & 1.49 & 0.37 & 0.39 & \\
\hline The company uses modern and & 3.08 & 1.44 & 0.46 & 0.30 & \\
\hline
\end{tabular}


ISSN 2278-5612

\begin{tabular}{|c|c|c|c|c|c|}
\hline Construct and item & Mean & SD & $\begin{array}{l}\text { Item to total } \\
\text { correlation }\end{array}$ & $\begin{array}{l}\text { Scale alpha if } \\
\text { item deleted }\end{array}$ & Reliability \\
\hline \multicolumn{6}{|l|}{ appropriate equipment and technology } \\
\hline $\begin{array}{l}\text { The facilities and buildings with nice } \\
\text { appearance and distinctive }\end{array}$ & 2.96 & 1.49 & 0.57 & 0.38 & \\
\hline $\begin{array}{l}\text { The company's internal design offers a } \\
\text { cozy atmosphere for you }\end{array}$ & 2.83 & 1.43 & 0.56 & 0.31 & \\
\hline $\begin{array}{l}\text { Waiting halls in the company is } \\
\text { comfortable }\end{array}$ & 2.79 & 1.46 & 0.51 & 0.37 & \\
\hline $\begin{array}{l}\text { The company provides clean sanitary } \\
\text { facilities }\end{array}$ & 2.78 & 1.43 & 0.38 & 0.31 & \\
\hline $\begin{array}{l}\text { Different company sites suitable for } \\
\text { customers and can be reached easily }\end{array}$ & 2.77 & 1.43 & 0.33 & 0.41 & \\
\hline Communication & & & & & .70 \\
\hline $\begin{array}{l}\text { The company has highly skilled staff in } \\
\text { dialog and communication with customers }\end{array}$ & 3.99 & 1.26 & 0.45 & 0.55 & \\
\hline $\begin{array}{l}\text { The company's staff has the ability to } \\
\text { explain the characteristics of the service } \\
\text { provided }\end{array}$ & 3.84 & 1.43 & 0.41 & 0.42 & \\
\hline $\begin{array}{l}\text { The company's staff informs customers in } \\
\text { full what must be done when receiving } \\
\text { service }\end{array}$ & 3.81 & 1.32 & 0.50 & 0.41 & \\
\hline $\begin{array}{l}\text { The company's staff ensures that } \\
\text { customer has to understand what is } \\
\text { required from him }\end{array}$ & 3.76 & 1.41 & 0.38 & 0.42 & \\
\hline $\begin{array}{l}\text { The company to contact you when they } \\
\text { providing the new services }\end{array}$ & 3.66 & 1.22 & 0.49 & 0.61 & \\
\hline
\end{tabular}

Table (3) Scale Reliability of customer satisfaction

\begin{tabular}{|c|c|c|c|c|c|}
\hline Construct and item & Mean & SD & $\begin{array}{c}\text { Item to } \\
\text { total } \\
\text { correlation }\end{array}$ & $\begin{array}{l}\text { Scale alpha } \\
\text { if item } \\
\text { deleted }\end{array}$ & Reliability \\
\hline Customer satisfaction & & $\overline{717}$ & . & & 0.78 \\
\hline I have internal motivation to deal with the company & 3.46 & 1.63 & 0.75 & 0.69 & \\
\hline I have full satisfaction On the way of delivering service & 3.42 & 1.61 & 0.85 & 0.75 & \\
\hline $\begin{array}{l}\text { I have full satisfaction of the speed of response } \\
\text { regarding complaints introduced by customers }\end{array}$ & 3.33 & 1.62 & 0.88 & 0.77 & \\
\hline $\begin{array}{l}\text { I have full satisfaction of the staff skills when providing } \\
\text { service }\end{array}$ & 3.27 & 1.53 & 0.72 & 0.74 & \\
\hline I have full satisfaction of the staff treatment of me & 3.41 & 1.55 & 0.68 & 0.66 & \\
\hline $\begin{array}{l}\text { I have full satisfaction of the speed of services provided } \\
\text { by the company }\end{array}$ & 3.32 & 1.58 & 0.72 & 0.66 & \\
\hline $\begin{array}{l}\text { I have full satisfaction of the means of communication } \\
\text { used to communicate with the company }\end{array}$ & 3.22 & 1.46 & 0.72 & 0.67 & \\
\hline $\begin{array}{l}\text { I have full satisfaction of the facilities available in the } \\
\text { company }\end{array}$ & 2.95 & 1.38 & 0.63 & 0.61 & \\
\hline I convince my friends to deal with the company & 2.71 & 1.36 & 0.48 & 0.41 & \\
\hline
\end{tabular}

\section{CORRELATION ANALYSIS}


A Pearson's correlation analysis was carried out to examine the bivariate relationships among the main variables. Table $\mathrm{V}$ displays the results of the correlation analysis of the study variables.

Table (4) Summary of correlations

\begin{tabular}{|c|c|c|c|c|c|c|c|c|c|}
\hline Variables & Mean & S.D & $\mathrm{CO}$ & CR & RE & RES & AS & TA & COM \\
\hline Competence & 2.95 & 1.07 & 1 & & & & & & \\
\hline Credibility & 2.96 & 0.95 & $0.42^{\star \star}$ & 1 & & & & & \\
\hline Reliability & 3.17 & 0.96 & $0.48^{\star *}$ & $0.34^{* \star}$ & 1 & & & & \\
\hline Responsiveness & 3.87 & 1.09 & $0.48^{\star \star}$ & $0.29^{\star \star}$ & $0.30^{* *}$ & 1 & & & \\
\hline Assurance & 3.61 & 1.00 & $0.52^{\star \star}$ & $0.27^{\star \star}$ & $0.24^{\star *}$ & $0.38^{\star *}$ & 1 & & \\
\hline Tangible & 2.92 & 0.91 & $0.51^{\star \star}$ & $0.26^{\star \star}$ & $0.37^{* \star}$ & $0.33^{\star *}$ & $0.29^{* \star}$ & 1 & \\
\hline Communication & 3.81 & 0.89 & $0.43^{* *}$ & $0.43^{\star \star}$ & $0.53^{* *}$ & $0.37^{* \star}$ & $0.43^{* *}$ & $0.24^{\star \star}$ & 1 \\
\hline
\end{tabular}

As can be seen in Table (4), the correlation coefficients for the variables under investigation were relatively high ranging from .24 to .53 . The results indicate that respondents had high levels of firms' service quality. Out of 21 correlations, all correlation coefficients are larger than .24. The highest coefficient of correlation in this research, however, is .52, which is below the cut-off of 0.90 for the collinearity problem. Hence, collinearity and multicollinearity do not represent data problems in this research (Hair et al., 1998).

\section{MULTIPLE REGRESSION ANALYSIS}

Multiple regression analysis was employed to examine the impact of service quality dimensions on customer satisfaction. It is a constructive statistical technique that can be used to analyze the association between a single dependent and several independent variables (Hair et al., 1998). Based on this method, the seven main independent variables (service quality dimensions) and dependent variable (customer satisfaction) were entered together. The detail of the regression output was shown in Table (5). Each of the variables had a tolerance value of more than 0.10 and a variance inflation factor (VIF) of less than ten. The finding indicated that the model had no serious multicollinearity problem (Hair et al., 1998). From these analyses, it can be concluded that multiple regression model of this study met the assumptions required to ensure validity of its significance test. This indicates that there was a statistically significant impact of service quality on customer satisfaction.

Table (5) Regression Summary

\begin{tabular}{|c|c|c|c|c|c|c|c|c|}
\hline & \multirow[t]{2}{*}{ MODEL } & \multicolumn{2}{|c|}{$\begin{array}{r}\text { UNSTANDARDIZED } \\
\text { COEFFICIENTS }\end{array}$} & \multirow{2}{*}{$\begin{array}{r}\text { STANDARDIZED } \\
\text { COEFFICIENTS } \\
\text { B }\end{array}$} & \multirow[t]{2}{*}{$\bar{T}$} & \multirow[t]{2}{*}{ SIG. } & \multicolumn{2}{|c|}{$\begin{array}{r}\text { COLLINEARITY } \\
\text { STATISTICS }\end{array}$} \\
\hline & & B & Std. error & & & & Tolerance & VIF \\
\hline \multirow[t]{8}{*}{1} & Constant & -0.049 & 0.239 & 1 & 2.204 & 0.039 & & \\
\hline & Responsiveness & 0.420 & 0.050 & 0.479 & 8.348 & 0.000 & 0.810 & 1.234 \\
\hline & Credibility & 0.175 & 0.060 & 0.173 & 2.920 & 0.004 & 0.760 & 1.316 \\
\hline & Tangible & 0.172 & 0.058 & 0.163 & 2.946 & 0.004 & 0.873 & 1.146 \\
\hline & Reliability & 0.140 & 0.060 & 0.141 & 2.342 & 0.020 & 0.742 & 1.348 \\
\hline & Competence & 0.167 & 0.031 & 0.207 & 5.308 & 0.000 & 0.657 & 1.522 \\
\hline & Communication & 0.076 & 0.029 & 0.108 & 2.664 & 0.008 & 0.656 & 1.525 \\
\hline & Assurance & 0.150 & 0.032 & 0.209 & 4.746 & 0.000 & 0.837 & 1.195 \\
\hline $\begin{array}{l}\text { Notes } \\
0.01\end{array}$ & 7 & & & & & & & \\
\hline
\end{tabular}

From the result as shown in Table (5), the R2 is .457, which means that 45.7 per cent of the variation in customer satisfaction can be explained by Competence, Credibility, reliability, responsiveness, Assurance, tangibles, Communication. Table (5) also shows that Responsiveness $(B=.42, p<0.01)$, Credibility $(B=.175, p<0.05)$, Tangible $(B$ $=.172, p<0.05)$, Reliability $(B=.14, p<0.01)$, Competence $(B=.167, p<0.05)$, Communication $(B=.076, p<0.05)$, and Assurance $(B=.15, p<0.01)$ had a significant and positive effect on customer satisfaction. Responsiveness $(B=.42$, $p<$ 0.01 ) has a highest significant effect on Responsiveness. This provides evidence to support $\mathrm{H} 1 \mathrm{a}, \mathrm{H} 1 \mathrm{~b}, \mathrm{H} 1 \mathrm{c},, \mathrm{H} 1 \mathrm{~d}, \mathrm{H} 1 \mathrm{e}$, $\mathrm{H} 1 \mathrm{f}$, and $\mathrm{H} 1 \mathrm{~g}$. Based on the values, Responsiveness has the highest impact on customer satisfaction. 


\section{FINDINGS}

This study was conducted to find out the impact of the provided service quality represented in its dimensions (Competence, Credibility, reliability, responsiveness, Assurance, tangibles, Communication) on customer satisfaction. The study found that there is a variation in the attitudes of the sample individuals towards the dimensions of service quality, at which the dimension of tangible ; due to the decent appearance of company employees, in addition to the beautiful and distinctive appearance for the equipment of the company buildings and interior design which provides a cozy atmosphere for the sample individuals. Regarding Assurance factor due to the feeling of the sample individuals that they are assured to deal with the company in addition to providing risk-free services. Regarding Competence factor attributed to the deductive capabilities of company employees which enable them to carry out their roles, in addition to having high qualifications in providing the service and trying to do their roles optimally. Reliability factor is attributed to the company's ability to provide services free of errors, on time and without delay, in addition to the company's ability to provide its services correctly from the first time. Responsiveness factor attributed to the full readiness of employees to provide assistance to the sample individuals, as well as the provision of the signboards in the company in order to speed up service. Credibility factor which attributed to the feeling of the sample individuals of the credibility of the company in implementing its services and the bills issued by the company are accurate and truthful. The communication factor due to the company's highly skilled staff on dialogue and communication and they have high capabilities to explain the characteristics of the provided service. The results of the study have also showed that the attitudes of the study sample individuals toward satisfaction factors were medium, and thus the attitudes of sample individuals are positive about satisfaction factor that is attributed to the satisfaction of the sample individuals about available the equipment in the company and the treatment of staff for them.

\section{RECOMMENDATIONS}

Through the results of the study reviewed by the researcher, he recommends the following:

- Concerning about providing advice and guidance to customers regarding the provided services to them, so that these services match the nature of their business.

- Full commitment by the promises being advertised or promises that are agreed upon with the customers.

- Discussing the prices of its services, so that these prices suit the provided services and the living conditions of the customers.

- Commitment by the offers provided to the customers, so that the advertised offers should match the reality.

- Great attention to complaints made by customers and considering them seriously by forming specialized committees to respond to these complaints.

- Working on the development of signboards in all centers of the company which include the steps to be followed by customers to receive the service in order to let the customer receives the service quickly and without errors or delay.

- Training and developing human resources, especially cadres in the front lines by involving them in specialized training courses.

- Giving the staff of the front lines some of the powers that help in facilitating the provision of the service and contribute to the participation of workers to take decisions that affect the essence of providing and delivering the service, at which it is reflected on the level of quality of the provided service.

- Recruiting employees of a high level of efficiency and being familiar with the procedures of obtaining the required services by customers in order to inform the client about how to get the required service, and to make sure that the customer understands what is required from him.

\section{REFERENCES}

[1] Abdel-Qader M.,(2002). Marketing Policy and Services, the glory of the university corporation for Studies, Publishing and Distribution, Jordan.

[2] Al-Allaq, B, Al- Taei,, H. Abdul Nabi (2007), Marketing Services, Zahran for Publishing and Distribution, Amman, 2007.

[3] Al-Dhmour H. H.,(2002). Marketing Services, Wael for publishing, Jordan.

[4] Al-Enezi, N. O., (2002) Measuring the Quality of Services Provided by STC, unpublished master thesis, Yarmouk University.

[5] Al-Hasri A. S., (1985). On the Arab Cultural Unity, Center for Arab Unity Studies, Beirut.

[6] Al-Shati,, J. M. (1993), Making Production Quality and Competition, Journal of Economics and Business, Vol 14, No.58. pp.52-78.

[7] Al-Taweel H. A.,(1996). Educational Management and Organizational Behavior, the Behavior of Individuals and Groups in the Systems, Amman, Wael for Printing and Publishing, Jordan.

[8] Andreson, E. WFornell,C.,\& Lehmann,D. (1994)," Customer Satisfaction, market Share and profitability: finding form sweden, journal of Marketing.VOL.58, July.

[9] Brian P (1998),"service Quality and Human Resource management ,A Review and Research Agenda ",Personal Review, Vol.27 No .1, pp.57-77.

[10] Daaboul M. Z,(2003). The Principles of Marketing Services, Al-Radhi for Publishing, Damascus - Syria.

[11] Gounaris, S.P., Stathakopoulos, V. and Athanassopoulos, A.D. (2003), "Antecedents to perceived service quality: an exploratory study in the banking industry", International Journal of Bank Marketing, Vol. 21 No. 4, pp. 16890. 
[12] Gronroos, A. (1984). Service Quality Model \& Its Marketinig Implictions ",European journal of marketinig, VOL.18, NO.4, pp.36-44.

[13] Hair, J.F. Jr, Anderson, R.E., Tatham, R.L. and Black, W.C. (1998). Multivariate Data Analysis, 5th ed., Prentice-Hall International, Upper Saddle River, NJ.

[14] Hakesever,C., and Render, B. , and Russell, R.S., and murdick ,R.G, (2000) "Service management and Operations " prentice Hall ,Inc. Upper saddle River, new jersey.

[15] Havra .T, (1995) "selling after the sale", Bank Marketing, Vol.27, No.1, pp.27-30.

[16] Hijazi J. T.,(2001). The Impact of Organizational Culture in the Effectiveness of crisis management system in Saudi commercial banks, Journal of Commercial Research, Volume 23, Issue 2,pp.201-233.

[17] Kotler P. and Armstrong G., (2001). Principles of marketing, ninth edition, Prentice hall international, Inc, USA.

[18] Lam, T., Wong, A. and Yeung, S. (1997), "Measuring service quality in clubs: an application of the SERVQUAL instrument", Journal of Hospitality Marketing, Vol. 4 No. 1, pp. 7-14.

[19] Melani , F., (1999). "The Effects of Internal communication,Leadership and Team Performance on successful service Quality Implementation -A south African Perspective " Team Performance management : An International Journal, Vol. 5 No.5, PP.150-163.

[20] Metawa, S. A., and Almossawai. M., (1998) " Banking Behavior of Islamic Bank Customers: Perspective and Implications", International Journal of Bank Marketing, Vol. 16, No.7, pp.299-313.

[21] Nelson T.sang \& Hailin Qu , (2000). Service Quality in China's hotel industry: a perspective from tourists \& hotel managers, International J. of Contemporary Hospitality Management, VoL.(12), No (5), P.P 316-326.

[22] Parasuraman, A., Zeithaml, V.A. and Berry, L.L. (1988), "SERVQUAL: a multiple-item scale for measuring consumer perceptions of service quality", Journal of Retailing, Vol. 64 No. 1, pp. 12-40.

[23] Parasurman, A, Zeithaml, V\&, Berry, L,(1985). "A Conceptual Model of Service Quality \& Its Implication for Future Research", J of Marketing, VOL. 49, NO.4, P.P 41-50.

[24] Ramaswamy Rohit (1996), design and management of service processes , Addison-wesley publishing company , INC.

[25] Roa ., A. (1996), TQM: A Cross Functional Perspective, John Wiley \& sons, USA.

[26] Robert b.Denhardt (1991).: PA: An Action orientation, Pcific Grove, California, USA, Brooke / Cole Publishing Co.

[27] Sekaran Uma, (2000), Research Method for Business, John willy and Sons Inc. , Third Edition.

[28] Station W. J ., (1967). fundamental's of Marketing, New York . MC-Grow, Hill ,Bookco,1967.

[29] Zeithaml. V.A, (1988) "consumer perceptions of price, quality and value: A means -End model and synthesis of evidence, " Journal of marketing 52, July, pp 2-22. 